\title{
Cooperation Between the European Union and Libya about Migration and Asylum: The Eventual Creation of Disembarkation Platforms
}

\author{
Lorena M. CALIOMNRISCAL
}

\begin{abstract}
1bstracl: During the so-called migration crisis, Libya has become a key partner for the European Union. From the $20 y_{j}$ European Agenda on Vigration to the Memorandum of Understanding between Italy and Libya, several declarations and financial instruments have followed one another, focusing mainly on the need to improve Libyan infrastructures that manage migration within their land and maritime borders. However, the failure of relocation and resettlement measures, the growing lack of solidarity among the Member States of the EU and the terrible perception for Europe of the loss of innocent lives at its exernal borders, renews the approach of possible politic al solutions that include the creation of enclaves in third states where migrants rescued at sea are disembarked. The aim of our paper is to analyse the June 2018 proposal for the creation of agreements with third states for the disembarkation of rescued migrants in the Vediterranean, and to highlight the legal issues arising from the delocalization of border control in a territory like Libya.
\end{abstract}

Kevwords: Disembarkation arrangements, deterritorialization, European Inion and Libya cooperation, extraterritorialization, eviernalization.

\section{(1) IXTROD)L CTIO)}

The gradual transfer of migration control policy to third countries during the so-called refugee crisis has been the progressive tendency of the European Union (EU) with the consequence, whether intended or not, of avoiding possible responsibility in matters of asylum law and refugee law. However, this reinforcement of cooperation bonds involves countries with questionable standards of compliance with human rights obligations and refugee law, such as Libya. Indeed, despite the lack of a legally binding partnership framework between the EU and Libya', this third country has become a significant partner for the EU. Thus, it has benefited from numerous EU political and financial instruments².

¿r Irlicle published on.31 December 2019

PhD Researcher in Public International Law and International Relations, University of Cádiz (lorena.calvo a .uca.es). Research Group «Centro de Estudios Internacionales y Europeos del Área del Estrecho» SEJ 572-, from the Andalusian Research Plan, whose Lead Researcher is Dr. Alejandro del Valle Gálvez, Full Professor of Public International Law and International Relations of the University of Cádiz.

Libva has alwass remained on the sidelines of formal entry into European initiatives for international cooperation with Mediterranean countries. Hence, there is no conventional partnership framework between the EU and Libya, and Libya has not joined the European Veighbourhood Policy either. Libya only participates as an observer in the so-called Barcelona Process' and in most of the Conferences of Ministers of Foreign Affairs and meetings of the Euro-Mediterranean Committee. J. Ferrer Lloret, 'La Unión Europea ante la crisis libia, derecho internacional, democracia y derechos humanos en las relaciones euromediterráneas?' 41 Revisla de Derecho Comunilario Europeo (2012) I6, at I8.

2 The main poliev instruments include the Commission's Joint Communication, «igration on the Central Mediterranean route Vanaging flows, saving lives» of 2. January 2017 and the «alta Declaration be the members of the European Council on the external aspects of migration: addressing the Central Vediterranean route» of 3 Februarv 2017 . Both documents place particular emphasis on the successive training, equipment and support programmes for the Libvan Border Guard, and the exchange of information on both sides of the Mediterranean. The financial assistance currently being provided by the EU to Libya comes mainly from two instruments: the European Veighbourhood Instrument (EVI) and the Instrument 
The unsuccessful relocation and resettlement measures, the increased lack of solidarity between the Member States and the negative image for Europe caused by the loss of innocent lives at its borders, renews the idea of possible political solutions including the creation of spots in third countries where migrants rescued at sea ${ }^{3}$ would be disembarked. These potential solutions are considered as a further example of operational and financial efforts to prevent people from leaving countries of origin and transit and from getling into European territory.

The aim of our work is therefore to analy se the $2018 \mathrm{EU}$ 's proposal to create agreements with third countries for the disembarkation in the latter of people rescued in the Mediterranean and then address the main legal issues raised by the outsourcing of border control to a territory like Libya.

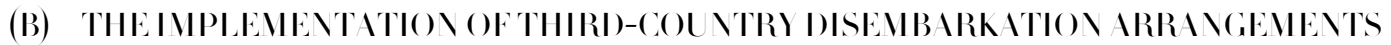

The summer of 2018 was a controversial period where countries such as Italy or Malta refused to allow undocumented migrants rescued by NGOs to disembark in their ports. In this context, an informal meeting was held on 2/4une $2018^{\prime}$ among a small group of I leads of Government of the Member States ${ }^{j}$, convened by the then President of the European Commission, Jean-Claude Juncker. Following this meeting, the European Commission published on 2/ June a follow-up document on the legal and practical feasibility of disembarkation options ${ }^{6}$, in where possible scenarios for disembarkation in the territory of a third state were explored.

It is not established in any of the cases whether the EU would work or deploy officers in these third states, as only the United Nations Iligh Commissioner for Refugees (UNICR) and the International Organization for Migration (IOM) would be in charge of ensuring that people in need of international protection could benefit from resettlement programs in the EU. It also recognizes that EU legislation would not need to be amended beyond resettlement commitments, so that the guarantees set out in the

Contributing to Stability and Peace (ICSP). Mowever, the financial instrument specifically developed to tackle the issue of irregular migration and displaced people in Africa is the EU Emergener Trust Fund (EU TF), born on the basis of the European Migration Agenda and launched with the Vallelta Summit on immigration in Vovember 20ry.

3 Proposals to relocale the asylum procedure itself or the procedure for identifying people in need of international protection from those who are not, is not new in any case. In 2003, the British Government already proposed this outsourcing mechanism, which would be carried out through the creation of 'regional protection areas' and 'transit processing centres' in third transit countries close to the countries of origin. Despite the EU-wide rejection at that time, several Ministers from other Member States, such as Germanx in 2005, or more recentl Denmark and Austria in 2018 , have begun to propose similar positions to outsourcing the examination of applications for international protection. However, the difference todav is that it is the EU institutions themselves that have relaunched the debate on the extraterritorialization of the asv lum procedure.

4 European Commission Information Vote: Informal workingmeetingon migration and as lum issues Brussels, 22 .June 2018.

5 Including representatives of the Governments of Spain, Greece, France and Germany, among others. See more information here.

6 European Commission, "The legal and practical feasibilits of disembarkation options. Follow-up to the informal working meeling, 2/.06.2018. 
Requirements ${ }^{7}$ and Procedure Directives ${ }^{8}$ would not apply, although identification and registration actions are being implemented ${ }^{9}$. A third option was also considered, whereby all irregular immigrants arriving in Europe, whether they are seeking asylum in the EU or not, would be sent directly to the territory of the third State to apply for asylum from there (extraterritorialization of the asylum procedure). Ilowever, the European Commission in the same document rejects this option for violating the principle of nonrefoulment, EU and international law.

It was the European Council under the Austrian Presidency which, in its conclusions of 28 June $2018^{10}$, invited the Council and the Commission to examine the concept of regional disembarkation platforms', to be implemented in 'close cooperation with the relevant third countries, as well as U NIICR and IO M'. In addition to changing the word 'agreements' to 'plat forms', it does not delimit the third States with which cooperation to this end would be undertaken, nor under what legal framework. The only expressed idea — which could evoke a possible extraterritorialization of the procedure, not of the asylum's striclo sensu, but of the identification of immigrants - is that such platforms should operate distinguishing individual situations, in full respect of international law and without creating a pull-factor'.

This European Commission document of 2/. July 2018 consists of a compromise, without any legally binding value, to implement, as far as possible, the creation of regional agreements for the disembarkation of people rescued in maritime operations". To this end, two general objectives are established: first, the compliance with international law and the principle of non-refoulement in debarkations, which must take place in a safe port; and, secondly, joint responsibility between all the actors involved and in cooperation with the U NIICR and IOM'2 regarding the post-disembarkation process.

7 Directive 2011/95 EU of the European Parliament and of the Council of 13 December 2011 on standards for the qualification of third-country nationals or stateless persons as beneficiaries of international protection, for a uniform status for refugees or for persons eligible for subsidiary protection, and for the content of the protection granted. (O.J L.337, 20.12.20II, p. $926)$.

8 Directive $20133_{2}^{2}$ EU of the European Parliament and of the Council of 26 June 2013 on common procedures for granting and withdrawing international protection. (O.J L I80, 29.6.201.3. p. 6o- 9.).

9 S, Marinai, 'Evtraterritorial Processing of Asylum Claims: Is it a Viable Option?', 12 IDirilli Umani e Dirillo Inlernazionale (2018), 3, p. 487.|ISS \: 1971-7105|

1) European Council, conclusions adopted at the European Council meeling Brussels, 28 June 2018. (EU CO g I8).

" Tote the change back to the concept of 'agreement' and not 'platform', which differs from the previous proposal of the European Council.

12 It was precisely on the dav after the European Council Conclusions that IO M and U NIICR published a joint proposal for a regional cooperation agreement to ensure predictable disembarkation and subsequent processing of persons rescued at sea'. The fact that this document was made public one das later is significant, as it denotes the interest of both International Organisations to distance themselves from the concept of "disembarkation platforms', pointed out by the European Council and from the purely externalizing vision (ECRE, 2018: 7). This document goes beyond the simple externalization of the identification and ass lum procedure, and refers to the need to establish a 'common approach' among all countries on both sides of the Mediterranean, with the main objective of "implementing a responsible and predictable disembarkation mechanism, in the EU or in other states, that prioritises human rights and safetuness' of rescued people, in the light of international law, refugee law and the principle of non-refoulement. It does not establish a particular solution, nor does it set out mandates or responsibilities for any particular state, but it does specify the main provisions and stages that must be observed in future formalised agreements between the states inolved. 
According to the Commission, potential third-country partners should include those States with existing cooperation agreements, taking into account the political, legal and security situation, as well as the extent of respect for human rights. The EU would provide "political, operational and financial support to establish regional disembarkation agreements in cooperation with third countries, U NIICR and IOM'. Besides, it only expressly states its commitment to cover:

- the costs of disembarkation and the subsequent procedure, especially in the areas of equipment, training and other ways to increase the capacities' of the competent authorities for controlling the external borders of third countries,

- financing reception centres so that they can have appropriate conditions that respect human rights standards, and

- support in the identification of vulnerabilities, referrals, case processing, Refugee Status Determination.

To specific actions or responsibilities on behalf of the EU or any of the EU Member States' officials are considered. Therefore, it is assumed that disembarked people are under the responsibility of the third State in which the disembarkation takes place. Consequently, both the reception and identification procedure would be carried out under the third State's law, just with the operational assistance of U NIICR and IOM, and the financial support of the EU. When establishing the necessary steps to be followed for the disembarkation, the Commission points out that, firstly, the place of disembarkation must be predetermined so that, secondly, these rescued people would be brought to the reception facilities as quickly as possible. It can, therefore, be understood that possible disembarkation platforms differ physically from the centre in which migrants are to be registered, identified and assisted'3.

Is far as people in need of international protection are concerned, there is no prospect of any extraterritorial asylum application process existing or likely to exist in respect of any EU Member State (competent in any case in matters of asylum law). In this non-paper, the EU pronounces itself most clearly when it comes to avoiding the existence of 'call effects'. In the paragraph dedicated to potential refugees, it is expressly states that:

it should be ensured and clearly communicated that resettlement possibilities will not be available to all disembarked persons in need of international protection. Resettlement should remain only one of the possible solutions for such cases, and not limited to Europe.'

In other words, it can be inferred from this analysis that the EU is committed to continuing strengthening financial cooperation to improve the capacities of African transit States. The main objectives would be the effective control of their external borders and facilitate the possible and legally disembarkation there, instead of providing a legal and humanitarian European response to migration from the territory of third States

3 Intentionally or not, the current President of the Spanish Government, Pedro Sánchez, in one of his speeches at the Congress, placed special emphasis on the fact that European Union law would be fully applied in these disembarkation centres. RTVE, 'Pedro Sánchez: las plataformas europeas para desembareo de migrantes propuestas por Vacron, una respuesta solidaria". 27.06.2018. 
The EU has clearly strengthened its operational and financial cooperation with Libya on migration control outside the EU's external borders. For this reason, it is relevant to consider the International and European legal implications of the potential creation of disembarkation platforms in Libya.

\section{(1) Deterritorialization: externalization and extraterritorialization}

Before addressing other issues, the policy of cooperation described must be conceptually clarified. To this end, we may refer to the distinc tion made by Del V alle Gálvez between three concepts: deterritorialization, externalization, and extraterritorialization't'. If we bear in mind that the legal connection between the EU Member States and Libya's practice of migration control is blurred depending on the deterrence measure used, establishing a specific legal conceptual framework could provide arguments for determining the possible jurisdiction and responsibility of the EU and its Member States in matters of human and refugee rights.

Given the growing confusion of terms and the variety of designations used to describe the notion of transferring border control functions to the territory of third countries, Del Valle Gálvez considers the concept of deterritorialization to refer to the idea of "locating outside European territory certain border control functions and migration policies to be carried out by other States or by the State itself"5. Within this concept, the author establishes a double distinction: externalization, including those situations in which it is the third state which '... carries out certain border control and migration policy functions |... as a direct or indirect consequence of agreements with the EU or with EU Member States, or with Programmes and Action Plans agreed with the European Union or its states ${ }^{216}$; and extraterritorialization, by which agents or public personnel from the EU Member States would be displaced for the exercise of public functions of migratory control, in such a way that there would be direct or indirect exercise of state jurisdiction, applying EU Law or the internal law of a Member State' outside their borders'7.

It is therefore necessary to examine the real intention of the EU with regard to the establishment of arrangements or platforms in third countries, since in the event that it constitutes an element of European ownership, or is managed under its authorities, it would be seen as a way of extraterritorializing migration control, which would trigger new concerns regarding the jurisdiction and application of EU human rights obligations.

(2) Law fulness of possible disembarkation platforms in Libya

‘. A. Del Valle Gáltez, 'Refugiados y crisis migratorias: fronteras y desterritorialidad en las puertas de Europa', in S. Ripol Carulla (coord), Jornadas sobre Derecho, Inmigración y Empresa, Colegio Volarial de Calaluña (Marcial Pons Ediciones Jurídicas y Sociales, Madrid, 2019), p. 108.

${ }^{5}$ Ibid, p. 20.

16) Ibid, p. 22.

17 Ibid, p. 22. 
Most of the legal problems raised by the creation of disembarkation platforms and or agreements in /with third countries are caused by the lack of accuracy of the European institutions' documents. This is so because the proposal does not recognizthe the true intention of the EU and its Member States as promoters of the initiative: whether to build this type of structures whose ownership belongs to the EU or one of its Member States -extralerrilorializalion-; or, on the other hand, whether only to finance its creation, with ownership remaining in the third State where it is created-externalization-. This distinction is essential in order to know who is responsible for guaranteeing the obligations relating to the international protection of those who are rescued and disembarked.

In 2010, for post-disembarkation aspects relating to the extraterritorial procedure for asylum applications, UNIICR drafted a policy guidelines document for the extraterritorial processing of international protection ${ }^{18}$, considering how to proceed in situations where the disembarkations were carried out in a State other than the State of the nationality of the vessel's flag. The most relevant to our sludy are two:

(เ) Third state processing model: whereby the application for international protection is processed and decided by a State other than the State of the nationality of the vessel. The third State must be a State party of the 1951 Geneva Convention for the Protection of Refugees and must also have a solid national asy lum system to ensure the observance of their human rights. In this case, there would be a transfer of responsibility for international protection from the rescuing State to the State of disembarkation.

(2) Out of country model: The State of the vessel, that intercepts migrants, is responsible for the asy lum procedure of those who request it, but it is carried out in the territory of a third State (the State where the disembarkation takes place).'

The development of the EU's strategy to create third-country disembarkation arrangements, previously analy sed, may suggest some similarities with the models already studied by U NIICR.

\section{(a) European-owned debarkalion plalforms and receplion centres (extralerrilorializalion)}

In the case of a legally binding international treaty between the EU or its Member States and a third State ${ }^{19}$ for the establishment of disembarkation centres in the latter, this treaty must comply with the provisions of the 1969 Vienna Convention on the Law of Treaties (VCLT) ${ }^{20}$. Therefore, it cannot go against certain norms of human rights protection ${ }^{21}$, considered of ius cogens (Art. 73 VCLT), nor should it violate the

is U I Iligh Commissioner for Refugees (U VICCR), Prolection Policv Paper: Varilime interceplion operations and the processing of international prolection claims: legal slandards and policv considerations wilh respect lo extralerrilorial processing, November 2010.

19 This kind of cooperation is possible under the legal framework provided by Art. $78(\mathrm{II})(\mathrm{g})$ and (d) of the Treaty on the Functioning of the EU.

$20 \quad V$ ienna Convention on the law of treaties. Concluded at Vienna on 23 May 1969 (U. X.T.S., vol. u.j.j)

${ }_{21}$ Such as the prohibition of violence (art. 2. IV of the U nited Vations Charter); prohibition of genocide and crimes against humanity (art. 3 of the Geneva Conventions of r949); right to life (art. 6 of the International Covenant on Civil and Political Rights - ICCPR); prohibition of racial discrimination (art. 7 and 9 of the ICCPR); and the prohibition of slavery and torture (art. 7 and 8 of the ICCPR), 
principle of non refoulement $t^{22}$ since this "constitutes an obligation of international customary law, created by the practice of States and crystallized through this Declaration ${ }^{23}$ and the Geneva Convention on Refugee Law²!

This case would be similar to the 'out of country model' analysed by U NIICR in 2010, where the EU would be in charge of the reception procedure and asylum applications in the third State. The problem, in this case, would lie in the exercise of asy lum sovereignty within these European-owned establishments. This is so because the EU does not currently have the competence to initiate or carry out asylum procedures on its own, but depends, in any case, on the exercise of Member States' competence over the right to asy lum. The EU could only support Member States in a financial and operational basis to carry out such procedures for the admission of asy lum applications following their national legislation ${ }^{25}$. Thus, it must be enshrined in an international treaty to that purpose for a Member State to be able to exercise its sovereignty in the area of asylum as well as to develop its own system of international protection in the territory of a third State.

Therefore, if the asylum procedure remains a national institution, although it is harmonised by the Directives of the Common European Asylum System (CEAS), would the CE AS itself be applied extraterritorially on those disembarkation stages, namely the Procedural and Qualification Directives? The most plausible conclusion is negative, as the CEAS is a territorial institution. This acquis communautaire in the field of asvlum, as Abrisketa Uriarte states

was expressly conceived with a purely territorial vocation, since all the directives and regulations contained therein allude to the rules of procedure and reception within the Member States for granting or withdrawing international protection ${ }^{206}$.

In fact, Art. 3 of the Procedural Directive itself explicilly excludes applications submitted to the consular or diplomatic representations of the Member States from its scope. Iowever, since it is a Member State that has responsibility for the asy lum procedure, it is the national legal framework of that European State that would apply, even if it is harmonized by the CE IS. It could be understood, therefore, that European law applies, through Directive $201 / 95 \mathrm{EU}$ on requirements, which could be applied extraterritorially ${ }^{27}$, and consequently the application of the EU Charter of Fundamental Rights would also be extraterritorialized.

If migrants intercepted at sea are immediately returned to the platform without a prior procedure of identification and study of the individual circumstances, we might also be in a case of collective expulsion,

${ }_{22}$ A. Künnecke, 'Legal Challenges and the practicability of disembarkation centres for illegal migrants outside the EU'. Real Institulo Elcano (2019), ARI 53 2019, p. 2.

23 The author refers to the ig67 I)eclaration on Territorial Isvlum, U \G I Res. 232 (XXII), I/ December I967.

- G. Fernández Arribas, 1silo y refugio en la U nión Europeca, Comares, Granada, 2007, p. 13.

25 A. Künnecke, Legal Challenges... supra n. 20, p. 1.

26 Translation is ours. J. Abrisketa U riarte, 'La dimensión externa del derecho de la U nión Europea en materia de refugio y asilo: un examen desde la perspectiva del non-refoulemeni'. Revisla de Derecho Comunilario Europeo, 2017, 56, p. 19.5. doi: hllps: doi.org 10.180,2 cepe rdce.j-jo.04

${ }_{27}$ European Council on Refugees and Eviles (ECRE) (2018). Isvlum at the European Council 2018: ()utsourcing or Reform? Poliey paper n. 4.p. ıo. 
explicitly prohibited by Protocol q of the European Convention on Iluman Rights (ECIIR). This would be applicable because a European element, such as the rescue ship or the plat form itself, would be involved, despite being outside EU territory. Furthermore, in the case of Libya, the conditions in which the country is immersed make the return to this territory an automatic breach of the principle of non-refoulement because of the risk of inhuman or degrading treatment. In this respect, there is also no provision for the possibility of a legal remedy, nor to which EU State or entities could the persons concerned be directed to do so. Besides there being no legal remedy and, in the hypothetical event that the asylum application is rejected, it would also be necessary to conclude readmission agreements with third countries, since the consequence would be, otherwise, that migrants would be trapped in countries as is the case in Libya, bearing in mind the svstematic violation of human rights there.

The European-owned platform could not be argued to be considered a safe country', since disembarkation centre in a non-safe third country is not a 'country' in the strict sense of the term, because it does not meet any legal requirement to be considered a State ${ }^{28}$. And the jurisdiction that a Member State could exercise in these centres - this being understood as the inherent competencies of state sovereignty - would also not be understood as a spatial projection of this State ${ }^{29}$. In other words, if these disembarkation platforms were to be set up in Libyan territory, as it is the hypothesis of our study, the principle of non-refoulement would never cease to be breached in the event that people rescued by European vessels in the Libyan territorial sea or on the high seas were to be transferred there.

It would be this ype of delocalisation that would allow us to argue a possible causal link between the European element present in the territory of the third State with the violation of an obligation of human rights or the right of refugees, to which the issuing State, which in this case we understand to be the EU or one of its Member States, is obliged, in order to determine the scope of its jurisdiction and, therefore, its possible international responsibility. In this case, the EU would be exercising a public authority activity such as managing people who are disembarked on these platforms in Libya.

The same would apply to the operational cooperation that the EU has deployed in Libya through the EU B A M Libya Mission or Operation EU N I F FR Med. If there is any breach of an international human rights obligation by an actor in such operations, there could be less doubt about the attribution of international responsibility to the EU. Therefore, any human rights violations under its jurisdiction would be attributable to the EU, as reflected in the Draft Articles on Responsibility of International Organizations adopted by the International Law Commission in $20 n$ (arts. 6 to 9 "Altribution of conduct to an international organization').

\section{(b) Third Slale-owned disembarkalion plalforms and receplion centres}

Throughout the development of the proposal for the creation of disembarkation agreements or platforms in third countries, the Commission, in its various published documents, has alwavs referred to the fact that

\footnotetext{
28 A. Künnecke, Legal Challenges... supra n. 20, p. 7

29 A. Sánchez Legido, ‘Héroes o villanos?' las O\G de rescate y las políticas europeas de lucha contra la inmigración irregular: (a propósito del caso Open Arms)’, ,6 Revisla General de Derecho Europeo (2018), p. 28.
} 
the Union would only bear the costs of disembarkation and of equipping and strengthening the authorities and reception centres of the State with which the agreement is established, so that conditions improve in a way that does not infringe human rights. In fact, even this same institution refused to outsource the asylum or return process to a third State $3^{3^{\circ}}$. This leads to the idea that the EU's purpose is not so much to establish the asylum procedure there, with the consequent establishment of legal channels for transferring those who are recognized as asylum seekers to European territory in a legal and safe manner. We should note that the Commission's non-paper, studied above, expressly states that resettlement is not available to all people in need of protection, and there is no guarantee that it will only take place on EU territory.

This situation is similar to the 'third state processing model' scenario contained in the UNIICR's 2010 extraterritorial protection policy proposal, in which the third state itself would be responsible for the postdisembarkation procedure. The problem comes when no Jorth African State has an asylum system that fully guarantees the international protection of refugees and asylum-seekers. For example, in the case of Libya, there is no asvlum procedure similar to that harmonized in the EU through the CE AS, as it does not even provide for its own national asylum system, it fails to fulfill the few regional obligations in the area of refugee law and it does not guarantee the non-violation of human rights because of the precarious situation of its institutions.

Concerning this indirect cooperation in general, it is true that the EU and Libya do not have a specific agreement stating that Libya will strengthen its border controls and manage migratory flows under EU control or at the expense of the EU. However, the financial instruments that the EU has mobilized during the refugee crisis towards Libya are precisely aimed at creating a Libyan Border Guard that is capable of patrolling independently in its territorial water, and preventing immigrants and asylum seekers from crossing into the Mediterranean with the aim of reaching European territory.

There is no doubt that a comprehensive rescue mission is necessary for the Mediterranean sea, but Libya, under continuous blackmail by violent militias and armed groups, needs stability before the beginning any kind of cooperation in relation to the rescue of migrants and refugees ${ }^{3}$. In these cases, it would be difficult to establish a jurisdictional link between the Union's financial and technical cooperation and Libya's violation of fundamental rights on its territory.

\section{(I)) CONCLUDI\GREM TRKS}

I. Not only may Libya not be considered a safe third country $3^{32}$, it is not even a safe country of origin. Today it is a State from which migrants themselves want to flee. The EU's constant cooperation with Libya

\footnotetext{
$3^{30}$ European Commission, 'The legal and practical feasibility of disembarkation options'. Follow-up to the informal working meeting, 2/.06.2018. op. cil., p. 9.

3' M. Giuffre, 'From Turkey to Libva: The EU migration partnership from bad to worse'. Eurojus (2017), 4 (1), p. 7.

$3^{2}$ Within EU law, safe country clauses are contained in Directive $20133^{2}$ EU on common procedures for granting or withdrawing international protection (OJ L I80, 29.6.2013, p. 60-9.). A safe third country is defined as a third State in which the applicant will not be threatened because of race, religion, nationalits, membership of a particular social group or political opinion; there is no risk of serious harm; the principle of non-refoulement is respected; and there is the possibility of applying for some mechanism of international protection ( Art. $3^{8)}$. With regard to the concept of safe country of origin, established in
} 
and the substantial financial efforts directed at the neighbouring country lead one to be lieve that the Union is not pursuing an externalization of the asylum procedure on Libyan territory per se, but is trying to get Libya to develop its own effective border management and control system, as well as the internal asylum infrastructure. Thus, it is Libya that should protect potential refugees, and could then be regarded as a safe third country. This support is motivated by the expectation of having fewer asylum seekers arriving in the EU or even by the possibility of sending them back to Libs ${ }^{33}$.

2. The proposals for the creation of disembarkation platforms or agreements in third countries born, this time, inside the $\mathrm{EU}$ institutions, have raised numerous concerns and uncertainties in the field of international law and EU law regarding the exercise of sovereignty and control of such enclaves located outside the territory of the Union. The vagueness of the provisions of the various communications and decisions studied, coupled with rhetoric that seeks to avoid at all costs the assumption of responsibilities for international protection, leads us to the conclusion that the EU's intention is not to copy the models of extraterritorial asylum procedures promoted by countries such as Australia or the United States. On the contrary, it would be erected as yet another measure of financial cooperation, in addition to those already developed by instruments such as the EUTF for Africa. Libya, being the Vorth African country that receives the most financial and operational support from both the EU and Italy, justifies the study of a possible agreement that would even entail an attempt to disembark people rescued at sea, despite the fact that the Foreign Minister of the Liby an Government has stressed that Tripoli opposes the EU plan for the establishment of centres for migrants outside the borders of the Community bloc ${ }^{34}$.

3. Having studied the greater or lesser implication of the jurisdiction of the EU or its Member States outside European territory, it can be stated that, in the event that a European national procedure is extraterritorialized in a country such as Libya, there would be a connection that would admit the application of the EU Charter of Fundamental Rights and the European Convention on Human Rights (ECIIR) for non-compliance with its provisions. Itowever, the problem lies in the fact that there is no such element of jurisdiction outside the Union, but that the EU merely finances activities that are to be carried out by third States, either by creating processing mechanisms within the territory of the third State, or by patrolling in its territorial sea or in the Iligh Sea. In these cases, there are imaginative solutions by which certain responsibility could be attributed for aid and assistance, or direction and control ${ }^{35}$, which must, in

Art. $3^{6,}$, it is said that a country mas be considered as safe country of origin for an applicant, alwavs after an individual examination of the application, if the applicant is a national of that country or, if being stateless had his habitual residence in that country, and has not been able to prove the existence of persecution in accordance with the legislation. If the applicant cannot prove individual persecution in his country of origin, it would lead the Member State to reject the application not because it is inadmissible (as in the previous case) but because it is unfounded.

33 P. García Andrade; I, Martín; S. Mananashvili, El cooperalion with third countries in the field of migration. Bruselas: Parlamento Europeo, 2015. PE $53^{6.1699, p .}$ 彳 $^{2}$.

31 Europa Press, 19-10-2018. «ibia rechaza el plan de la L E para establecer centros para migrantes fuera de las fronteras delbloque».

35 In these cases, reference is made to Arts. I6 and iz of the Draft Articles on International Responsibility of States, drafted by the International Law Commission in 20ot, which establish State responsibility in relation to the act of another State in cases where the first State aids or assists or carries out directing and controlling acts towards another State in the commission of an 
any case, be fundamental and decisive for the third State that commits the internationally wrongful act. The application of the Charter and the jurisdiction of the EU Court of Justice has even been proposed, simply through direct or indirect financial cooperation ${ }^{36}$.

4. The EU should reconsider its strategy and focus even more on the protection of human rights. To do this, it requires solidarity between all Member States, something that is getting further and further away when the spectre of xenophobia continues to haunt Europe. The EU has the means to create safe pathways by which to bring those in need of protection to EU territory but lacks the political will to do so. That is the reason why African and Middle Eastern countries themselves are still the ones that receive the largest number of refugees and migrants, despite being much less developed and having less capacity than those of the Union itself. The situation deteriorates when those partners, who become necessary co-operators of the EU in the management of immigration, fail to comply with the standards for the protection of human rights and cause the lives of migrants and asylum seekers to be a real nightmare. Although we are aware of the legal challenge of establishing a link between the EU's cooperation policy and the possibility of international responsibility for persistent human rights violations in Libya, the options explored in our work can help us to elucidate the extent to which the EU is consistent with its development cooperation policy and its own values.

internationally wrongful act provided that it 'does so with knowledge of the circumstances of the act' and if such an act would also be considered internationally wrongful if committed by the State providing aid or assistance.

$3^{6}$ Authors such as Carrera and Cortinov is define the concept of 'portable responsibility' as a functional approach to the applicability of EU fundamental rights in cases where migration control is extraterritorialized. This would imply that the EU Charter of Fundamental Rights would apply in any situation that refers to the Union without the criterion of territoriality being decisive', Carrera, S. y Cortinovis, R. (2019). Search and rescue, disembarkation and relocation arrangements in the Mediterranean. Sailing Away from Responsibility.' CEPS paper in Liberly and Securily in Europe, n. 2019-10, June 2019 , p. 10. See also: Moreno-Lax, V. and Costello, C. (201/). "The Extraterritorial Application of the Charter: From Territoriality to Facticity, the Effectiveness Model', in S. Peers, T. Marvey, J. Kenner and A. Ward (eds.), Commentary on the EU Charter of Fundamental Rights, O\ford: Hart Publishing, pp. 16 $67^{-168} 3$. Specifically, both authors affirm that whenever a Member State or EU authorities cooperate with a third State or its institutions, directly or indirectly, their responsibility must be asse ssed in the light of the fundamental rights of the EU, where the right of asylum of art. 18 of the Charter would apply. For this responsibility to arise, it is sufficient to provide financial or technical assistance to a third State, whose cooperation results a violation of human rights. As the EU Charter of Fundamental Rights applies, it could be held accountable before the EU Court of Juslice itself (Carrera, S.y Cortinovis, R. Search and rescue, disembarkation... ibid. p. 1o). 